\title{
The effectiveness of chemotherapy and electrochemotherapy on ovarian cell lines in vitro
}

\author{
J. SACZKO ${ }^{1}$, J. PILAT ${ }^{1}$, A. CHOROMANSKA ${ }^{1}$, N. REMBIALKOWSKA ${ }^{1}$, J. BAR ${ }^{2}$, I. KAMINSKA ${ }^{2}$, J. ZALEWSKI ${ }^{3}$, J. KULBACKA ${ }^{1, *}$ \\ ${ }^{1}$ Department of Medical Biochemistry, Wroclaw Medical University, ${ }^{2}$ Department of Immunopathology and Molecular Biology, Wroclaw Medical \\ University; ${ }^{3}$ Department of Gynecology and Obstetrics, Wroclaw Medical University
}

${ }^{*}$ Correspondence: julita.kulbacka@umed.wroc.pl

Received October 1, 2015 / Accepted November 27, 2015

\begin{abstract}
The presented study aimed to evaluate in vitro the effectiveness of improvement standard chemotherapy with bleomycin by electroporation in two various ovarian cancer cell lines. Two human ovarian cell lines OvBH-1 and SKOV-3 were used. The lines were selected because of their resistance to several therapeutic methods. As anticancer drug we use range of concentrations of bleomycin. In EP and ECT experiments different voltage values: from 0 to $1200 \mathrm{~V} / \mathrm{cm}, 8$ pulses with duration of $100 \mu \mathrm{s}$ and intervals between pulses $1 \mathrm{~s}$ long were used. The cells viability after applied treatments was evaluated by MTT assay. The expression of heat shock proteins - HSP27 was examined by immunocytochemical ABC method.The cytotoxicity with different concentrations of bleomycin alone was not significantly decrease in both cell lines. It confirms resistance of these cells to conventional chemotherapy. The highest decrease of cell proliferation was observed after EP with bleomycin after $48 \mathrm{~h}$ of incubation for $1000 \mathrm{~V} / \mathrm{cm}$. The intensity of expression of small heat shock proteins HSP27 slightly increased after ECT in both treated cell lines, in particular in OvBH-1. The presented study indicated that application of electroporation may effectively enhance chemotherapy with bleomycin, particularly in the case of treating ovarian cancer resistant to standard therapy.
\end{abstract}

Key words: chemotherapy, electroporation, electrochemotherapy, bleomycin, ovarian cancer

Despite stable progress in the early detection of cancer and their treatment, tumors are still a large problem. Modern diagnostics and therapeutics generate real expectations of improvement of results of treatment. Ovarian cancer is one of the common and most lethal among gynecological tumors [1]. The pathogenesis of this cancer have been examined through a long time, but still it is poorly understood. Until now the aggressive surgery and standard chemotherapy have been engaged to improve the survival rate in patients with this cancer [2]. However the prognosis remains poor due to diagnosis in advanced stages only and have accumulation of mutations of the major oncogenes and/or tumor suppressor genes. Moreover the primary and secondary resistance of cancer cells is often involved in failure of generally used chemotherapeutic methods and limits the effectiveness of this treatment modality $[3,4]$. Nowadays, to generally used chemotherapeutic drugs for ovarian cancer treatment belong cisplatin and taxane derivatives $[5,6]$. Unfortunately only $15-$ $35 \%$ of patients respond positively on those treatment. The favorable treatment of cancer is dependent upon the efficiency of cytotoxic anticancer therapies either alone or in combination with other ways of treatment. The new diagnostic and alternative therapeutic methods with significantly increase of sensitivity and specificity are required. Electrochemotherapy is one of the new techniques. This method is based on combination of electroporation (EP) and chemotherapy [7]. EP improve transfer of chemotherapeutics, which don't have potential to diffuse through cell's membrane due to size and physicochemical properties, like bleomycin. The mechanism of EP is still not fully understood. The basic mechanisms of membranes within electric field is the polarization, which leads to EP. It is possible that the electric field forms the small nanopores in plasma membrane by applying strong, short, high voltage electric pulse, which lead to a new way to transport substance into cells. The result can be reversible when the plasma membrane is permeated only for brief moment $[8,9]$. There are two common medicines studied previous in electrochemotherapy with successful results: bleomycin and cisplatin $[10,11,12]$. Earlier the electroporation phenomenon was used to gene and larger molecules like DNA, RNA transferring [13, 
14]. Currently EP is applied widely in various biological and medical investigations $[15,16]$. Bleomycin is characterized as hydrophilic and impermeable drug, which transport through the plasma membrane is very restricted [17]. The combination of bleomycin and electroporation use significantly increases the effectiveness of cancer cells treatment. Similar results were also obtained with cisplatin $[9,12,18]$.

The aim of our investigation was to estimate the effectiveness of electrochemotherapy in comparison to standard chemotherapy with bleomycin in two various ovarian cancer cell lines revealing the resistance to standard chemotherapy.

\section{Materials and methods}

Cell lines. The investigations were performed on two different ovarian cell lines: OvBH-1- human clear ovarian carcinoma with silent mutation of P53 gene and resistant to chemo- and radiotherapy and SKOV-3 line-human ovarian carcinoma cells resistant to diphtheria toxin, cisplatin and adriamycin (ATCC Manassas, Virginia/USA). The first line was established at the Department of Clinical Immunology, Wroclaw Medical University from ascetic cells of a 54-years old woman with ovarian clear cell adenocarcinoma. The morphological, immunophenotype and temperature-sensitive behavior of these cells were characterized previous [3]. Both cell lines were grown in polystyrene flasks with $25 \mathrm{~cm}^{2}$ cell culture surface (Nunc, Denmark) as a monolayer in Dulbecco modified Eagle medium (DMEM, Life Technologies) at $37^{\circ} \mathrm{C}$ in $5 \% \mathrm{CO}_{2}$. DMEM was supplemented with $2 \mathrm{mM}$ L-glutamine, $10 \%$ fetal bovine serum (FBS, Sigma-Aldrich, Buchs/Switzerland) and $50 \mu \mathrm{g} / \mathrm{ml}$ streptomycin (SigmaAldrich). For the experiments the cells were removed by trypsinization (trypsin $0.25 \%$ and EDTA $0.02 \%$; SigmaAldrich) and washed with PBS.

The concentration of bleomycin. The chemotherapeutic agent bleomycin was used (Sigma-Aldrich). At first cells were incubated for 24 and $48 \mathrm{~h}$ with following concentrations of bleomycin: $1 ; 3 ; 7.5 ; 30 ; 75 ; 300$ and $750 \mathrm{nM}$. For further studies concentrations of bleomycin were selected by results from MTT assay (Sigma Aldrich).

Electroporation (EP). EP was performed using ECM 830 device (BTX Harvard Apparatus, Syngen Biotech, Wroclaw/ Poland), generating electrical pulses with the magnitude of 0-3000 V/cm , 10-600 $\mu$ s long, in the series of 1-99 pulses separated by the time interval of $100 \mathrm{~ms}-10 \mathrm{~s}$. The electroporation parameters were: a series of eight electric pulses of $800-1000 \mathrm{~V} / \mathrm{cm}, 100 \mu \mathrm{s}$ long, with the repetition frequency $1 \mathrm{~Hz}$. Cells in suspension were centrifuged for $5 \mathrm{~min}$ at $800 \mathrm{rpm}$ and resuspended in the EP buffer with low electrical conductivity ( $10 \mathrm{mM}$ phosphate, $1 \mathrm{mM} \mathrm{MgCl}, 250 \mathrm{mM}$ sucrose, $\mathrm{pH}$ 7.4) [19]. Cells were used for experiments after $10 \mathrm{~min}$ post electroporation to determine cell membrane conditions called "releasing time".

Electro-Chemo reaction (ECR). We examined the effect of electroporation on two different ovarian cell lines without (control cells) and with bleomycin. Before electric pulses delivery, respective volumes of bleomycin solution were added to the prepared EP buffer. Then EP was performed. The electroporation conditions in ECR were selected according to the sensitivity of cells to the electric field (previous study) [20]. After 10 min post electroporation cells were resuspended in culture medium without drug and used to further experiments.

Cells viability. The viability of cells was determined by MTT assay (Sigma Aldrich) after standard chemotherapy and electrochemotherapy. The MTT assay was used to estimation of mitochondrial metabolic function. For the experiment the cells were seeded into 96-well micoculture plates at $1 \times 10^{4}$ cells/well and grown overnight. After incubation with selected concentrations of bleomycin with electroporation or without, the assay was realized according to the manufacture's protocol. The absorbance was determined using a multiwell scanning spectrophotometer at $570 \mathrm{~nm}$ (Enspire Perkin Elmer Multiplatereader, Waltham, Massachusetts/USA). Mitochondrial function was expressed as a percentage of viable treated cells in relation to untreated control cells.

Immunocytochemistry of HSP27 proteins. Immunocytochemistry was performed using the peroxidise $\mathrm{ABC}$ labelling according to manufacturer's protocols (DAKO LSAB 2 kit, Dako, Glostrup/Denmark). The cells used for experiments were plated into 10-dip glass (Thermo Scientific, Waltham/ MA USA). The cultures were fixed and dehydrated using $4 \%$ paraformaldehyde for 10 minutes. The enzymes expression were visualised with rabbit monoclonal antibody (Santa Cruz Biotechnology, Dallas/Texas, USA). The samples were analysed with the upright microscope (Olympus BX51, Hamburg/Germany). Stained cells were determined by counting 100 cells in randomly selected fields. The result was assessed positive if staining was observed in more than $5 \%$ of cells. The intensity of immunocytochemical staining was evaluated as: (-) negative, $(+)$ weak, $(++)$ moderate and $(+++)$ strong. All experiments were repeated three times.

\section{Results}

The concentration of bleomycin. The cell viability was examined by MTT assay after 24 and $48 \mathrm{~h}$ incubation with various concentrations of bleomycin according to our previous study [21]. The results of drug screening for SKOV-3 and OvBH-1 cells were presented on the graphs 1 and 2. The investigation showed that both cell lines were generally resistant to bleomycin after 24 hours of incubation (Fig. 1A). However the mitochondrial activity after $24 \mathrm{~h}$ post incubation with various concentrations of bleomycin was above $50 \%$ but below control untreated cells in SKOV-3 cells. The viability of OvBH-1 cells was similar to control untreated cells (Fig 1A). After $48 \mathrm{~h}$ the cytotoxicity of bleomycin remained close to control level in both cell lines (Fig. 1B).

Electro-Chemo reaction (ECR). We examined the efficacy of ECR with selective 30 and $300 \mathrm{nM}$ concentration of bleomy- 
A

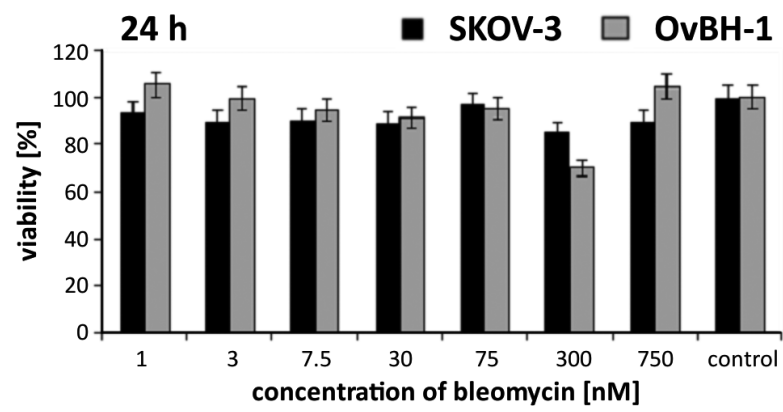

B

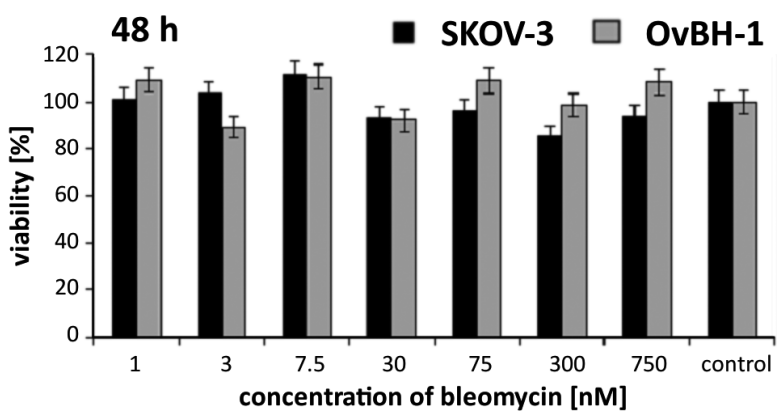

Figure 1. The impact of various concentration of bleomycin on the viability of SKOV-3 and OvBH-1 cells aafter 24 (A) and 48 (B) hours incubation.

cin in ovarian SKOV-3 and OvBH-1 cell lines in comparison to standard chemotherapy. After 24 hours of incubation post ECR with $300 \mathrm{nM}$ of bleomycin the significant therapeutic effect was observed in both ovarian cancers, although in
OvBH-1 was stronger (Fig. 2). Where $800 \mathrm{~V} / \mathrm{cm}$ electric field was applied for $300 \mathrm{nM}$ of bleomycin, the viability of OvBH-1 decreased to $42 \%$ and in SKOV-3 to 51\%. After electroporation with $1000 \mathrm{~V} / \mathrm{cm}$ the proliferation reduced to $29 \%$ and $40 \%$ in

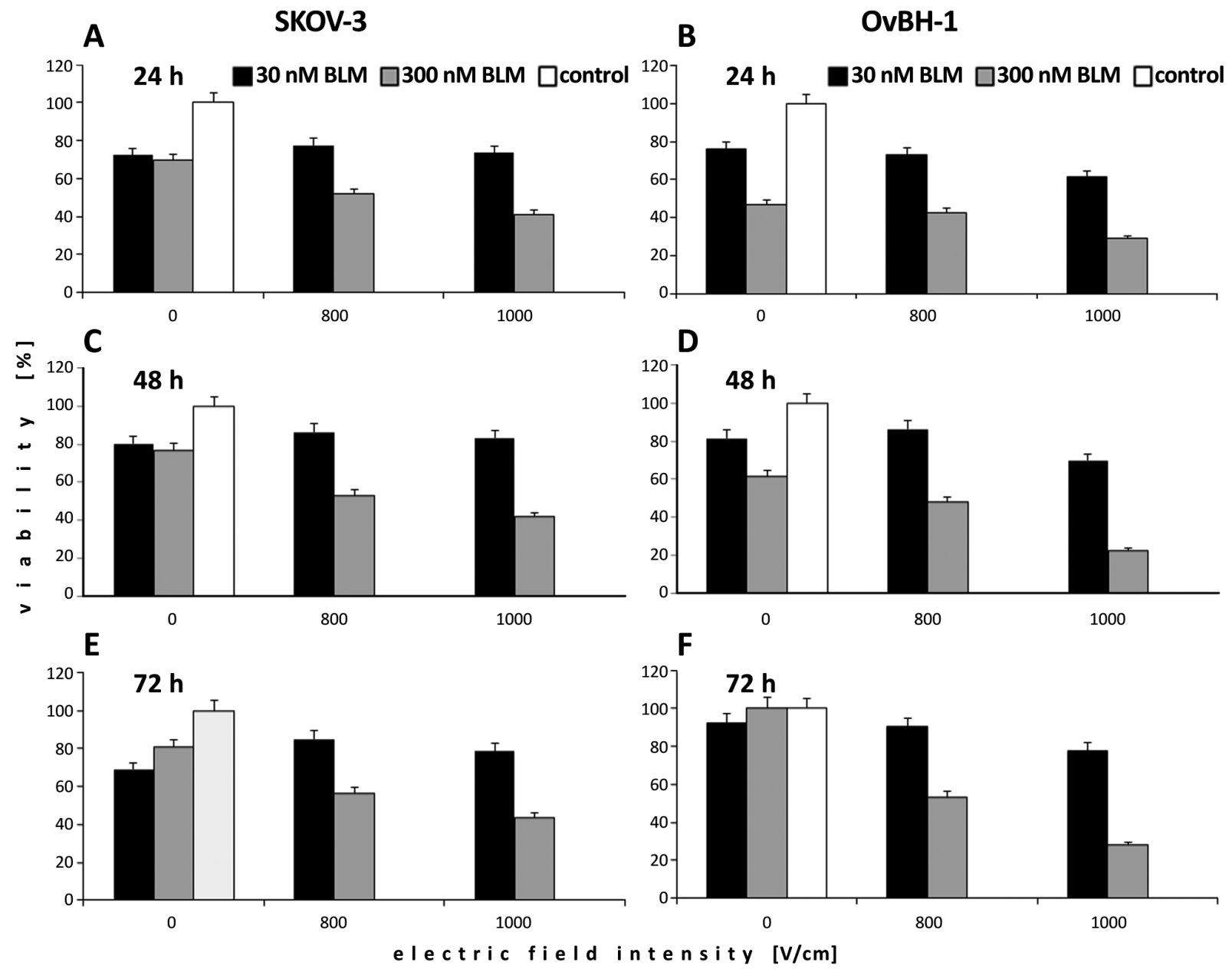

Figure 2. The effect of combined therapy (ECR) measured by viable cells after 24 hours in: (A) SKOV-3 and (B) OvBH- cell line; after 48 hours in: (C) SKOV-3 and (D) OvBH- cell line and after 72 hours in: (E) SKOV-3 and (F) OvBH- cell line. 

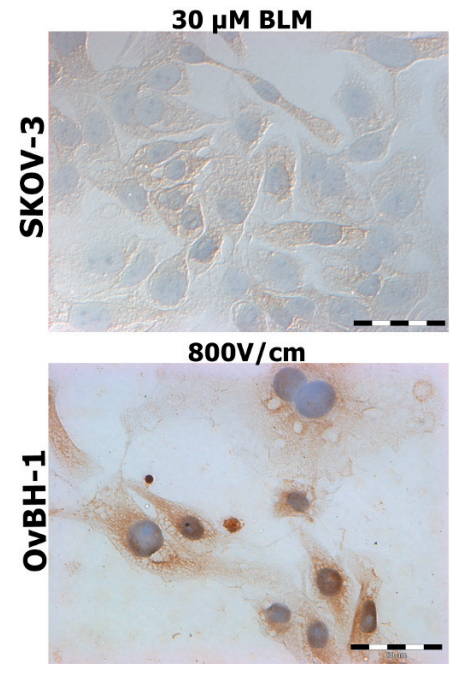

$1000 \mathrm{~V} / \mathrm{cm}$

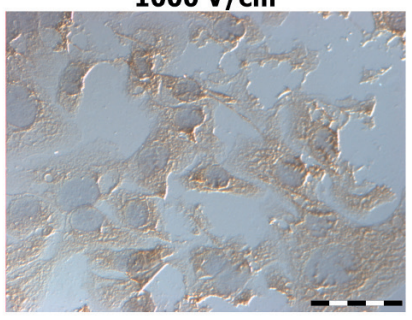

$300 \mu M$ BLM

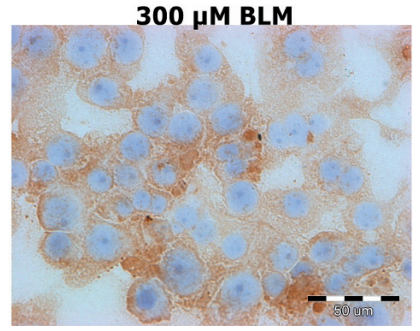

$800 \mathrm{~V} / \mathrm{cm}+30 \mu \mathrm{M} B L M$

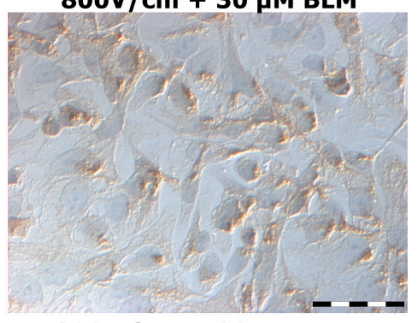

$800 \mathrm{~V} / \mathrm{cm}+30 \mu \mathrm{M} B L \mathrm{M}$

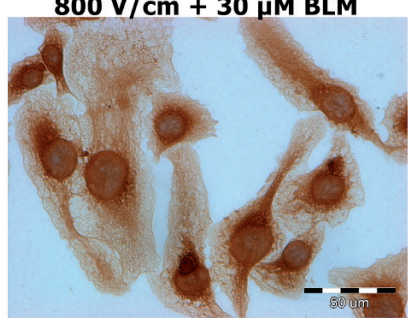

$1000 \mathrm{~V} / \mathrm{cm}+30 \mu \mathrm{M}$ BLM

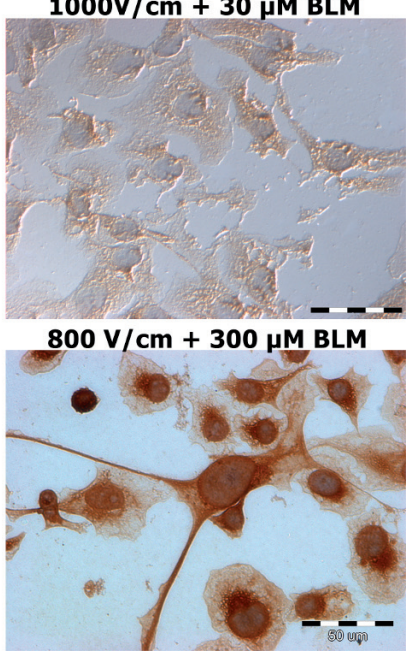

Figure 3. The immunocytochemical evaluation of HSP27 in ovarian cell lines after electrochemotherapy with bleomycin.

OvBH-1 and SKOV-3 cell lines respectively also for $300 \mathrm{nM}$ of bleomycin (Fig. 2A and B). Similar results were obtained after 48 and 72 hours post ECR for SKOV-3. The longer time of incubation ( 48,72 hours) caused more significant viability decreasing in $\mathrm{OvBH}-1$ cells particularly for applying therapy by $1000 \mathrm{~V} / \mathrm{cm}$ for $300 \mathrm{nM}$ of bleomycin. The dose $30 \mathrm{nM}$ of bleomycin was not sufficiently effective for both used electric field intensity in both cell lines $(800,1000 \mathrm{~V} / \mathrm{cm})($ Fig. $2 \mathrm{C}$ and D) and (Fig. 2E and F).

Immunocytochemistry of HSP27 protein. The immunocytochemical investigation are presented in the Table 1 and Fig. 3. The expression of HSP27 was evaluated before and after ECR with parameters established previously - EP: 800 and $1000 \mathrm{~V} /$ $\mathrm{cm}$ and bleomycin concentrations: 30 and $300 \mathrm{nM}$. SKOV-3 cells revealed slight immunocytochemical stained reaction of HSP 27 protein in comparison to OvBH-1 cells. A slight expression of HSP-27 was also observed in SKOV-3 cells post standard chemotherapy for both concentrations of bleomycin and after ECR with $800 \mathrm{~V} / \mathrm{cm}$ and $30 \mathrm{nM}$ of bleomycin $(<5 \%$ and $10 \%$ of stained cells respectively). The increased intensity of immunocytochemical reaction in SKOV-3 cells was observed after ECR $1000 \mathrm{~V} / \mathrm{cm}$ and $300 \mathrm{nM}$ concentration of applied drug ( $40 \%$ of stained cells). In OvBH-1 cells the expression of HSP 27 increased for each applied conditions of combined therapy. The lowest level of HSP 27 was after standard chemotherapy ( $10 \%$ for $30 \mathrm{nM}$ and $20 \%$ for $300 \mathrm{nM}$ of bleomycin). The most intense stained reaction was observed after ECR with $800 \mathrm{~V} /$ $\mathrm{cm}$ electric field intensity for both concentrations of bleomycin (97 and 100\% of stained cells respectively).

\section{Discussion}

Conventional ovarian cancer treatments, such as surgery, radio- and chemotherapy are not effective in many cases. Addi- tionally the drug delivery is often invalid and a lot of cancer cells are resistant to commonly used chemotherapeutics. Standard chemotherapy indicates high cytotoxicity and low survival rate in various cancers including also ovarian cancer. Electrochemotherapy is a new cancer treatment, which can be applied efficiently. It enables chemotherapeutic drugs dose reducing and eliminating drug side effects $[9,20]$. The application of the electric field to the cell membrane with cytotoxic drugs in environment could increase their uptake through malignant cells [7, 22]. In our studies we presented that both cell lines are resistant to various concentration of bleomycin in standard chemotherapy. After electric field application with intensity range 800

Table 1. The evaluation of immunocytochemical reaction with HSP27 antibodies in human ovarian cancer cell lines after ECR with bleomycin (the intensity of stained reaction was evaluated as: $(-)$ negative, $(+)$ weak, $(++)$ moderate and $(+++)$ strong).

\begin{tabular}{ccccc}
\hline Cell line & EP [V/cm] & $\begin{array}{c}\text { Concentration of } \\
\text { bleomycin [nM] }\end{array}$ & Intensity & $\begin{array}{c}\% \text { of positive } \\
\text { stained cells }\end{array}$ \\
\hline SKOV-3 & \multicolumn{2}{c}{ control cells } & - & 0 \\
& 0 & 30 & - & 0 \\
& 0 & 300 & - & $<5$ \\
& 800 & 30 & - & $<5$ \\
& 800 & 300 & + & 20 \\
& 1000 & 30 & + & 10 \\
& 1000 & 300 & ++ & 40 \\
\hline OvBH-1 & & control cells & - & 0 \\
& 0 & 30 & + & 10 \\
& 0 & 300 & ++ & 20 \\
& 800 & 30 & +++ & 97 \\
& 800 & 300 & +++ & 100 \\
& 1000 & 30 & + & 25 \\
& 1000 & 300 & + & 30 \\
\hline
\end{tabular}


and $1000 \mathrm{~V} / \mathrm{cm}$ with particularly one bleomycin concentration $(300 \mathrm{nM})$ the viability of both ovarian cancer cell lines were decreased. Bleomycin is commonly used toxic agent in standard chemotherapy, but its high cytotoxicity is restricted by poor diffuse through plasma membrane $[23,24]$. It has been shown in vitro studies, that less than $0,1 \%$ of bleomycin was penetrated into cells from extracellular medium [25]. The cytotoxicity of bleomycin was enhanced in hamster lung fibroblast to 300-700 fold after electroporation [26]. In our previous investigation we performed also the cytotoxic effect of 5-fluorouracil and cisplatin on ovarian cancer OvBH-1 and SKOV-3. After standard chemotherapy the viability of ovarian cancer cells remained about $50-70 \%$ of control cells. It is worth noting that both cell lines were resistant to cisplatin, which is commonly used in standard chemotherapy of ovarian cancers. The significant therapeutic effect in examined cell line was observed after electrochemotherapy with cisplatin and 5-fluorouracil [20]. Drug resistance is a frequent problem in cancer therapy. In ovarian cancer cases the resistance to cisplatin occurred very often. In opposite to cisplatin, bleomycin is not transported by P-glycoprotein [27, 28]. The major mechanism of resistance to bleomycin in cancer cells is connected with cytosolic enzyme - bleomycin hydrolase. However, increase of bleomycin hydrolase has been found only in some experiments $[29,30]$. The correlation between cytotoxic activity and the levels of bleomycin hydrolase in human ovarian carcinoma was not found [29].

The small heat shock protein (sHSP) family take part in protein quality systems (PQC), which are responsible for reduce of various environmental and cellular stress factors [31]. The levels of HSP chaperons are increased in many cancers, which is connected with poor prognosis of cancer [32, 33, 34, 35]. HSP27 is one of the small shock proteins. The high expression of this protein in ovarian and breast cancer cell lines has been associated with resistance to cisplatin and doxorubicin [36, 37]. We observed the increased expression in SKOV-3 to $40 \%$ and OvBH-1 cells to $60 \%$ after ECR $1000 \mathrm{~V} / \mathrm{cm}$ and $300 \mathrm{nM}$ concentration of bleomycin. It can be connected with activation of antiapoptotic response in examined cancer cells after anticancer treatment. The increase expression of HSP27 can indicate a damage in ovarian cells after electrochemotherapy with bleomycin. This type of chaperones is up-regulated in many cancers. That proteins play important roles in inhibition of cell death pathways and also can modulate pro-survival signaling and transcriptional networks. HSPs protect cells from various therapeutic stress factors which induce apoptosis [38]. HSP27 is greatly expressed in many cancers including breast and ovarian $[39,40]$. On the other hand it might correlate with good prognosis in some tumors like endometrial and others [41].

The results obtained in this work demonstrated that electric field increased effectiveness of chemotherapy with bleomycin. ECT with bleomycin is promising for both treated cell lines: $\mathrm{OvBH}-1$ and SKOV-3 and overcome the multidrug resistance of cells. It allows also for reducing the dose of bleomycin and side effects of applied therapy.
Acknowledgments: This work was supported by grant of Wroclaw Medical University No. PBmn-131 and partially by UMED Statutory Funds ST-882.

\section{References}

[1] KURMAN RJ, SHIH IE M. The origin and pathogenesis of epithelial ovarian cancer: a proposed unifying theory. Am J Surg Pathol 2010; 34: 433-443. http://dx.doi.org/10.1097/ PAS.0b013e3181cf3d79

[2] KIM A, UEDA Y, NAKA T, ENOMOTO T. Therapeutic strategies in epithelial ovarian cancer. J Exp Clin Cancer Res. 2012; 31: 14. http://dx.doi.org/10.1186/1756-9966-31-14

[3] BAR JK, WYRODEK E, GRYBOS M, GABRYŚ M. Immunohistochemical evaluation of neoepitope cytokeratin 18 expression in relation to $\mathrm{p} 53$ protein in ovarian carcinoma. Adv Clin Exp Med 2007; 16: 197-204.

[4] KUSAKARI T, KARIYA M, MANDAI M, TSURUTA Y, HAMID AA, et al. C-erbB-2 or mutant Ha-ras induced malignant transformation of immortalized human ovarian surface epithelial cells in vitro. Br J Cancer 2003; 89: 2293-2298. http:// dx.doi.org/10.1038/sj.bjc.6601423

[5] PFISTERER J, PLANTE M, VERGOTE I, DU BOIS A, HIRTE $\mathrm{H}$, et al. Gemcitabine plus carboplatin compared with carboplatin in patients with platinum sensitive recurrent ovarian cancer: an intergroup trial of the AGO-OVAR, the NCIC CTG, and the EORTC GCG. J Clin Oncol. 2006 24: 4699-4707. http://dx.doi.org/10.1200/JCO.2006.06.0913

[6] KUPRYJANCZYK J, MĄDRY R, PLISIECKA-HALASA J, BAR J, KRASZEWSKA E, et al. TP53 status determines clinical significance of ERBB2 expression in ovarian cancer. Br J Cancer. 2004; 91: 1916-1923. http://dx.doi.org/10.1038/sj.bjc.6602238

[7] MIR LM, GEHL J, SERSA G, COLLINS CG, GARBAY JR, et al. Standard operating procedures of the electrochemotherapy: instructions for the use of bleomycin or cisplatin administered either systemically or locally and electric pulses delivered by the CliniporatorTM by means of invasive or non-invasive electrodes. Eur J Cancer 2006; 4: 14-25. http:// dx.doi.org/10.1016/j.ejcsup.2006.08.003

[8] SKOLUCKA N, SACZKO J, KOTULSKA M, KULBACKA J, Electroporation and its application. Pol Merk Lek. 2010; 28: 501-504.

[9] KOTULSKA M. Electrochemotherapy in cancer treatment. Adv Clin Exp Med. 2007; 16: 601-607.

[10] GEHL J. Electroporation: theory and methods, perspectives for drug delivery, gene therapy and research. Acta Physiol Scand. 2003; 177: 437-447. http://dx.doi.org/10.1046/j.1365201X.2003.01093.X

[11] MIR LM. Application of electroporation gene therapy: past, current, and future. Methods Mol Biol. 2008; 423: 3-17. http:// dx.doi.org/10.1007/978-1-59745-194-9 1

[12] TODOROVIC V, SERSA G, FLISAR K, CEMAZAR M. Enhanced cytotoxicity of bleomycin and cisplatin after electroporation in murine colorectal carcinoma cells. Radiol Oncol 2009; 43: 264-273. http://dx.doi.org/10.2478/v10019-009-0037-5

[13] NEUMANN E, SCHAEFER-RIDDER M, WANG Y, HOFSCHNEIDER PH. Gene transfer into mouse lyoma cells 
by electroporation in high electric fields. EMBO J. 1982; 1: 841-845.

[14] HAAS K, SIN WC, JAVAHERIAN A, LI Z, CLINE HT. SingleCell Electroporation for Gene Transfer In Vivo. Neuron. 2001; 29: 583-591. http://dx.doi.org/10.1016/S0896-6273(01)00235-5

[15] WEAVER JC. Electroporation of Cells and Tissues. (IEEE) Trans. Plasma Sci. 2000; 28: 24-33. http://dx.doi. org/10.1109/27.842820

[16] ZUPANIC A, KOS B, MIKLAVCIC D. Treatment planning of electroporation-based medical interventions: electrochemotherapy, gene electrotransfer and irreversible electroporation. Phys Med Biol. 2012; 57: 5425-5440. http:// dx.doi.org/10.1088/0031-9155/57/17/5425

[17] GALM U, HAGER MH, VAN LANEN SG, JIANHUA J, THORSON JS, et al. Antitumor antibiotics: bleomycin, enediynes, and mitomycin. Chem Rev. 2005; 105: 739-758. http:// dx.doi.org/10.1021/cr030117g

[18] GOTHELF A, MIR LM, GEHL J. Electrochemotherapy: results of cancer treatment using enhanced delivery of bleomycin by electroporation. Cancer Treatment Rev. 2003; 29: 371-387. http://dx.doi.org/10.1016/S0305-7372(03)00073-2

[19] WEZGOWIEC J, KOTULSKA M, SACZKO J, DERYLO MB, ROLS MP, et al. Cyanines in photodynamic reaction assisted by reversible electroporation-in vitro study on human breast carcinoma cells. Photodiagnosis Photodyn Ther. 2013; 10: 490-502. http://dx.doi.org/10.1016/j.pdpdt.2013.04.004

[20] SACZKO J, KAMINSKA I, KOTULSKA M, BAR J, CHOROMANSKA A, et al. Combination of therapy with 5-fluorouracil and cisplatin with electroporation in human ovarian carcinoma model in vitro. Biomed Pharmacother. 2014; 68: 573-580. http://dx.doi.org/10.1016/j.biopha.2014.05.005

[21] MIR LM, BELEHRADEK M, DOMENGE C, ORLOWSKI S, PODDEVIN B, et al. Electrochemotherapy, a new antitumor treatment: first clinical trial. C R Acad Sci III. 1991; 313: 613-618.

[22] KULBACKA J, NOWAK M, SKOŁUCKA N, SACZKO J, KOTULSKA $M$. The influence of electroporation on in vitro photodynamic therapy of human breast carcinoma cells. Folia Biol (Praha). 2011; 57: 112-118.

[23] MITORO A, KURIYAMA S, TSUJINOUE H, MATSUMOTO M, NAKATANI T, et al. Electrochemotherapy with bleomycin against colorectal carcinoma in a mouse model: evaluations of the dose and administration route of the drug and the electric field intensity. Int J Oncol. 2000; 16: 97-104. http://dx.doi. org/10.3892/ijo.16.1.97

[24] TOUNEKTI O, PRON G, BELEHRADEK J JR, MIR LM. Bleomycin, an apoptosis-mimetic drug that induces two types of cell death depending on the number of molecules internalized. Cancer Res. 1993; 53: 5462-5469.

[25] ROY SN, HORWITZ SB. Characterization of the association of radiolabeled bleomycin A2 with HeLa cells. Cancer Res 1984; 44: 1541-1546.

[26] GEHL J, SKOVSGAARD T, MIR LM. Enhancement of cytotoxicity by electropermeabilization: an improved method for screening drugs. Anticancer Drugs 1998; 9: 319-325. http:// dx.doi.org/10.1097/00001813-199804000-00005
[27] LAZO JS. BLEOMYCIN. IN: CHABNER BA, LONGO D eds. Cancer Chemotherapy and Biotherapy. Philadelphia, Lippincott-Raven Publishers; 1996: 379-393.

[28] GOTHELF A, MIR LM, GEHL J. Electrochemotherapy results of cancer treatment using enhanced delivery of bleomycin by electroporation. Cancer Treat Rev 2003; 29: 1-2. http://dx.doi. org/10.1016/s0305-7372(03)00073-2

[29] LAZO JS, BOLAND CJ, SCHWARTZ PE. Bleomycin Hydrolase Activity and Cytotoxicity in Human Tumors. Cancer Res. 1982; 42: 4026-4031.

[30] MICHOR F, NOWAK MA, IWASA Y. Evolution of Resistance to Cancer Therapy. Curr Pharm Des. 2006; 12: 261-271. http:// dx.doi.org/10.2174/138161206775201956

[31] MACARIO AJ, CONWAY DE MACARIO E. Chaperonopathies and chaperonotherapy. FEBS Letters. 2007; 581: 3681-3688. http://dx.doi.org/10.1016/j.febslet.2007.04.030

[32] CIOCCA DR, CLARK GM, TANDON AK, et al. Heat shock protein hsp70 in patients with axillary lymph node-negative breast cancer: prognostic implications. J Natl Cancer Inst. 1993; 85: 570-574. http://dx.doi.org/10.1093/jnci/85.7.570

[33] CORNFORD PA, DODSON AR, PARSONS KF, DESMOND $\mathrm{AD}$, WOOLFENDEN A, et al. Heat shock protein expression independently predicts clinical outcome in prostate cancer. Cancer Res. 2000; 60: 7099-7105.

[34] BLAGOSKLONNY MV, FOJO T, BHALLA KN, KIM JS, TREPEL JB, et al. The Hsp90 inhibitor geldanamycin selectively sensitizes Bcr-Abl-expressing leukemia cells to cytotoxic chemotherapy. Leukemia. 2001; 15: 1537-1543. http://dx.doi. org/10.1038/sj.leu.2402257

[35] VAN, T VEER LJ, DAI H, VAN DE VIJVER MJ, HE YD, MAO $\mathrm{M}$, et al. Gene expression profiling predicts clinical outcome of breast cancer. Nature. 2002; 415: 530-536. http://dx.doi. org/10.1038/415530a

[36] Thanner F, SUTTERLIN MW, KAPP M, RIEGER L, MORR AK, et al. Heat shock protein 27 is associated with decreased survival in node-negative breast cancer patients. Anticancer Res. 2005; 25: 1649-1653.

[37] LANGDON SP, RABIASZ GJ, HIRST GL, KING RJ, HAWKINS RA, et al. Expression of the Heat Shock Protein H5P27 in Human Ovarian. Clinical Cancer Res. 1995; 1: 1603-1609.

[38] ALOY MT, HADCHITY E, BIONDA C, DIAZ-LATOUD C, CLAUDE L, et al. Protective role of Hsp27 protein against gamma radiation-induced apoptosis and radiosensitization effects of Hsp27 gene silencing in different human tumor cells. Int J Radiat Oncol 2008; 70: 543-553. http://dx.doi. org/10.1016/j.ijrobp.2007.08.061

[39] KAPOOR C, VAIDYA S. Heat shock protein (HSP) and cancer: An overview. Am J Med Dent Sci. 2013; 1: 31-34.

[40] ZOUBEIDI A, GLEAVE M. Small heat shock proteins in cancer therapy and prognosis. Int J Biochem Cell Biol. 2012; 44: 1646-1656. http://dx.doi.org/10.1016/j.biocel.2012.04.010

[41] THOMAS X, CAMPOS L, MOUNIER C, CORNILLON J, FLANDRIN P, et al. Expression of heat-shock proteins is associated with major adverse prognostic factors in acute myeloid leukemia. Leuk Res. 2005; 29: 1049-1058. http:// dx.doi.org/10.1016/j.leukres.2005.02.010 